
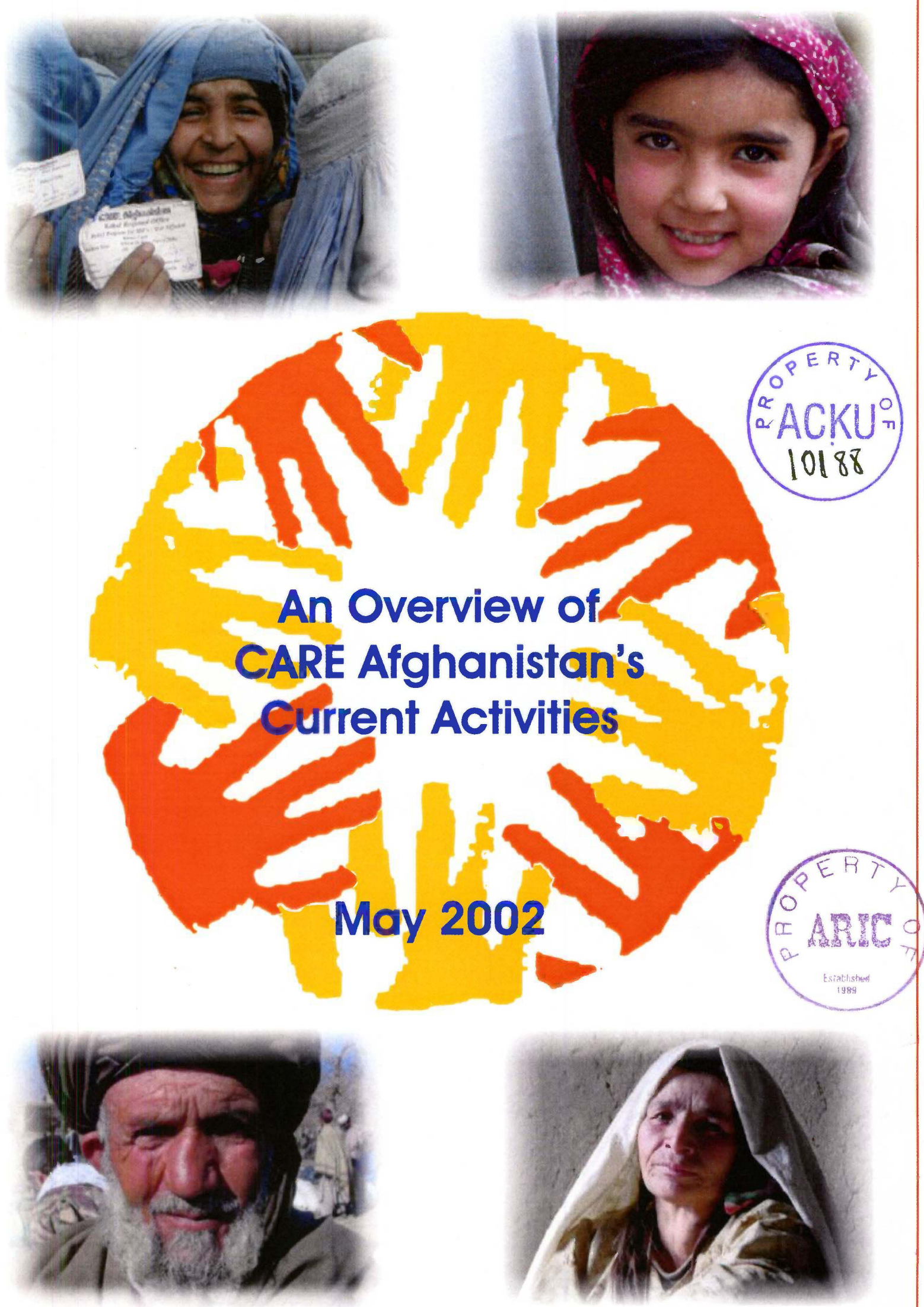
Even before the tragic events of September $11^{\text {th }}$ and the subsequent military campaign against Taliban and al-Qaeda forces, Afghanistan was already one of the world's most impoverished and war-ravaged countries. More than 20 years of military conflict and three years of drought have devastated much of Afghanistan, resulting in the collapse of basic social services and government infrastructure, widespread food shortages and the displacement of millions of people.

In early-October 2001, the US-led coalition forces launched its campaign in Afghanistan against the Taliban and al-Qaeda, leading to the collapse of Taliban rule and installation of the new Afghan Interim Authority (AIA) headed by Hamid Karzai on December 22nd. Despite the changes in political leadership and the new prospects for peace in Afghanistan, the country still faces many challenges.

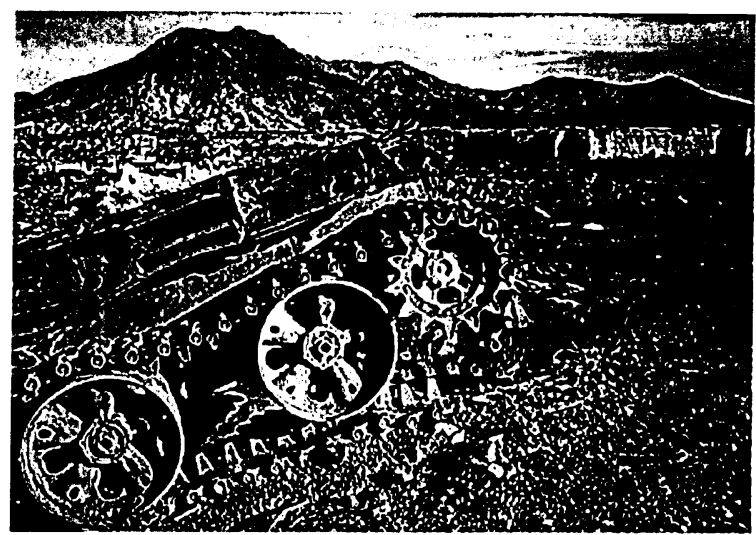

A primary concern is security. While Kabul remains relatively safe due to the presence of international peacekeepers (the International Security Assistance Force, or (SAF), insecurity in the form of armed conflict, kidnappings, robbery and banditry persist in many areas of thẹ country. In northern Afghanistan, many ethnic Pashtuns have been driven from their homes, brutally attacked and even killed because of anti-Taliban backlash. ${ }^{1}$ In other areas of the country, feuding warlords threaten to destabilize the country's tentative peace. There have been two assassination attempts, one successful, on high-ranking members of the AIA. Many humanitarian agencies have experienced vehicle thefts and office robberies, making work in areas outside of Kabul a constant and dangerous challenge. The presence of landmines and unexploded ordnance (UXO) throughout Afghanistan also poses a serious threat.

In addition to security concerns, the AIA will also face considerable challenges as it rebuilds the country's humanitarian and social service networks. When it came to power in the mid-1990s, the Taliban imposed its strict interpretation of Islamic law (already practiced in many rural areas) which excluded women from the workplace and, in most cases, prohibited girls from attending schools and female teachers from working. This contributed to an increase in poverty, especially for female-headed households in Kabul, where women had previously been able to work and pursue their studies. Widowed by war, many women have no means to provide for their families, and have relied on food aid for survival. Government support networks, including the ability to deliver the most basic health, education, and other social services, virtually collapsed over the last few years.

\footnotetext{
${ }^{1}$ The Taliban were comprised predominately of Pashtuns, but not all members of this large ethnic group supported the Taliban. Pashtuns are a minority in northern Afghanistan.
}

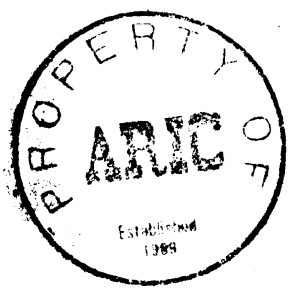


Moreover, the AIA must also help revitalize Afghanistan's shattered economy and infrastructure, including roads, schools, basic utilities and communication systems. Although there are adequate food supplies in most markets, prices for basic goods

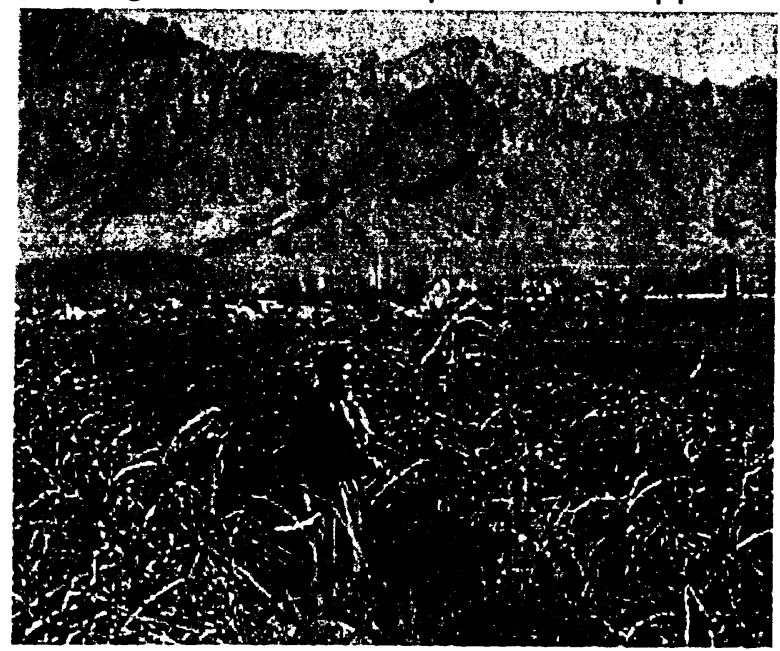
have increased. In urban areas such as Kabul, there are few opportunities for employment, especially for women. Rural areas continue to suffer the crippling effects of the long drought which has destroyed crops and caused people to move from their farms to seek new livelihoods. The UN estimates that some 3.5 million Afghan refugees are still living in Pakistan and Iran, and an additional 920,000 people remain displaced within Afghanistan because of drought and conflict.

In June 2002, Karzai and former Afghan king Zahir Shah will open a "loya jirga", or grand council meeting of leaders and representatives from across Afghanistan, to elect an 18-month transitional government leading up to elections. Over the last four months, Afghanistan has made tentative progress towards reconstruction, but more external assistance is required to rebuild the country's civil society and basic infrastructure and to ensure peace. After a two-day meeting in Tokyo in January, the international community pledged more than $\$ 4.5$ billion in foreign assistance, with most of the funding promised for the next two years. The United States pledged $\$ 296.75$ million for the first year.

Thanks to the generous outpouring of support from public and private donors, CARE has been able to mount a significant response to the humanitarian crisis in Afghanistan. CARE's presence in Afghanistan dates back to $1961,{ }^{2}$ and thus even before the tragic events of September $11^{\text {th }}$, CARE was committed to fighting root causes of poverty in Afghanistan. This report covers CARE's emergency relief and rehabilitation programmes in Afghanistan since September 2001, as well as providing an overview of its ongoing humanitarian assistance efforts.

\section{Programme Activities}

During the peak of the coalition bombing in Afghanistan, CARE suspended most of its activities due to security concerns for programme participants and staff. Two programmes remained operational, a girls' education project in rural areas and a water supply project in Kabul. Working from its office based in Peshawar, Pakistan, CARE sent in convoys of food and other relief supplies starting in November. In December, CARE expanded its emergency response activities, and has gradually resumed all of the suspended programmes. Demonstrating its renewed hopes for peace and security in Afghanistan, CARE moved its main administrative office from Peshawar to Kabul on March $21^{\text {st }}$.

\footnotetext{
${ }^{2}$ With a suspension of activities from $1980-1989$ due to insecurity.
} 


\section{CARE Target Areas}

CARE is currently operational in seven provinces of eastern Afghanistan (Kabul, Wardak, Logar, Paktia, Paktika, Khost and Ghazni Provinces). Working through local partners, CARE has expanded its reach to include Zabul and Kandahar Provinces in southeastern Afghanistan, and Badghis, Herat and Farah Provinces in western Afghanistan.

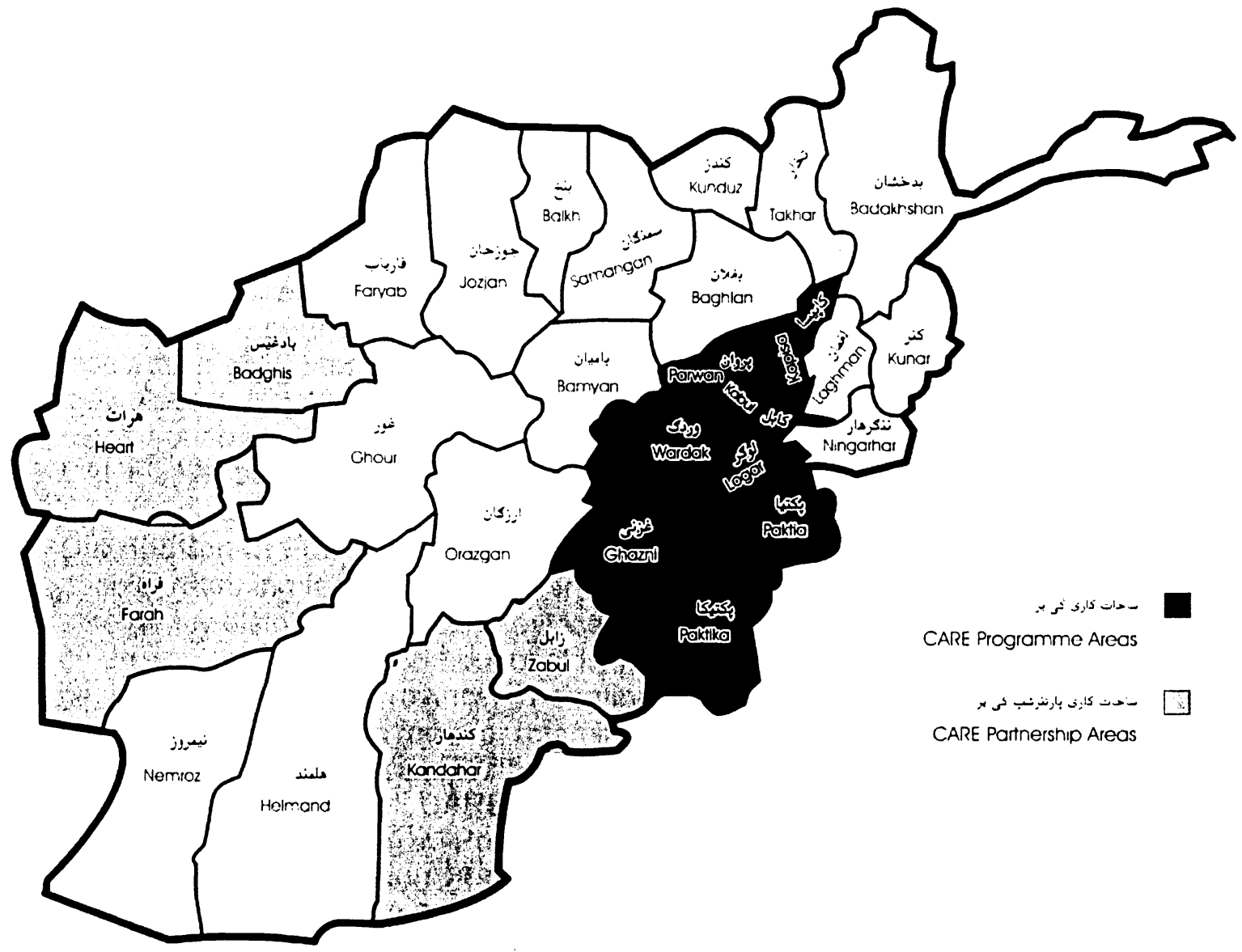

Within these areas CARE is working to address vulnerable communities' immediate and long-term needs through six major programmatic areas:

- Emergency Response: assisting communities affected by man-made and natural disasters

- Urban Water and Sanitation: providing clean water and health education

- Assistance to Widows: feeding programme and training for income generation

- Rural Assistance: community development and rehabilitation activities

- Basic and Girls Education: training teachers and providing materials and supervision to community-based schools

- Local Capacity Building: through partnership projects with Afghan NGOs

In addition to direct service provision, CARE is engaging in advocacy on key issues affecting Afghanistan to ensure a policy environment conducive to lasting peace and development in the country. 
A summary of CARE Afghanistan's emergency relief and poverty eradication programming since September $11^{\text {th }}$ is detailed below.

\section{Emergency Response}

Although CARE was implementing emergency assistance programmes in Afghanistan even prior to September $11^{\text {th }}$ (e.g., earthquake relief and drought assistance), they have expanded significantly in recent months. Some of the recent programmes have included:

- Food Distribution in Kabul and Logar Provinces: One of CARE's first emergency response activities post-September $11^{\text {th }}$ was the distribution of food to 1,000 displaced families in rural districts of Kabul and Logar provinces. This distribution of 100 tons of wheat took place in November and was carried out by AREA, one of CARE's key partner NGOs.

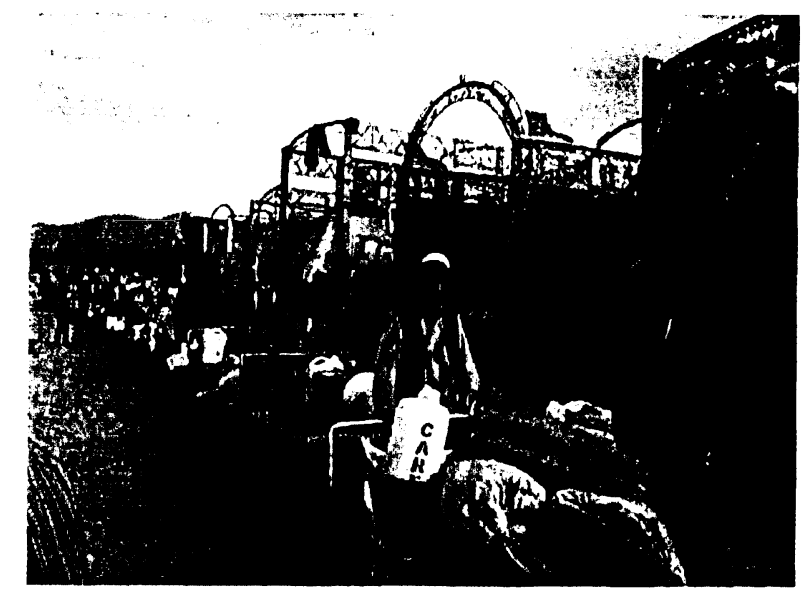

- Distribution of Food and Emergency Supplies: To assist internally displaced people, returning refugees and other vulnerable people, CARE carried out a emergency distribution in four provinces of Afghanistan. CARE provided emergency packs to 3,586 households in Parwan Province and 2,492 households in Kapisa Province. The ration of wheat flour, sugar cooking oil, and beans provided enough food for a family of six for 90 days. CARE also equipped vulnerable families for winter with quilts, shawls, tarps, buckets, soap and other essential items. In Kabul, CARE distributed a similar emergency pack to 5,000 poor households. In Ghazni Province, CARE distributed emergency kits to 8,000 of the most vulnerable households (and supported UNHCR's distribution efforts to reach an additional 10,000 households).

- Karez Rehabilitation: Rebuilding destroyed houses and basic infrastructure is a prerequisite for displaced Afghan families to return home. In the Shamali Valley area north of Kabul, CARE is helping communities rebuild the traditional "karez" well systems which provide clean drinking water and irrigate farmland in this largely agricultural area. The wells were dynamited and poisoned during the late 1990 s by the Taliban, in an effort to rid the villages of opposition supporters. Although the Shamali Valley is now relatively peaceful, the scars of war remain mined roads, demolished houses and schools, and burned fields and farmland. Using traditional technology and local expertise, CARE is helping rehabilitate 519 karez water systems in 169 villages in the region. The labourers receive a "salary" of food contributions (a three-month supply of wheat flour, sugar, oil and beans), thus providing employment and ensuring food security while the communities begin to rebuild. A total of 8,821 families will benefit from the foodfor-work activities, and approximately 230,000 people will have access to clean drinking water from the rehabilitated karez systems. 
Abdul Samad, aged 67, stands in front of the remains of his house in the Shamali Valley.

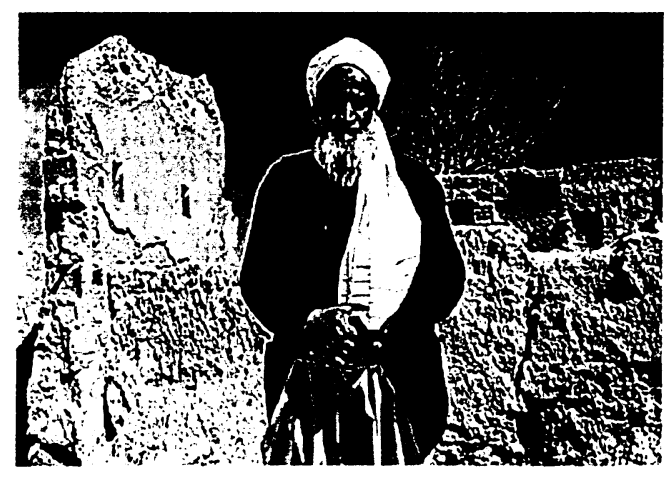

He recalls, "We used to live in peace here.

Our children were happy and played together, and we grew grapes, apples, apricots and peaches on our farms. The day we fled our house, we didn't have time to take anything, only the clothes on our backs. When I first returned and saw my destroyed home, I felt I had no hope left. Now I believe that if my home and village are rebuilt, I will return here." CARE is supporting karez rehabilitation and home repair in Abdul's village, working in partnership with community members.

- Shelter Construction: In addition to repairing the karez systems, CARE is also working to rebuild destroyed houses in the Shamali Valley with support from OFDA. Virtually all homes in this area were severely damaged, i.e., missing one or more walls and all or part of the roof. CARE is providing window frames and glass, doors, support beams and all skilled labour. The communities are providing the local labour and supplies. The project aims to rehabilitate 3,200 homes by September 2002. CARE also provided 400 tents to returning families.

- Emergency Assistance to Kabul: Through this project, CARE is helping decrease the vulnerability of 20,000 families in five districts of Kabul city through the provision of winterization packs and improved living conditions. CARE is providing cash-for-work opportunities for people who clean rubbish from the city streets, resurface roads and dig drainage ditches (see photo below). The project also winterizes houses by providing glass for windows and rehabilitating damaged homes.

- Drought Response and Mitigation: In response to the complex emergency, involving drought and conflict, CARE has undertaken large-scale interventions to meet the needs of the families who have remained in their villages. CARE's objective has been to protect against out-migration and further deterioration in human condition, while strengthening communities abilities to cope with future shocks. Using an adapted Food for Work approach CARE has implemented projects to decrease food shortage levels while assisting communities improve water supply systems essential for agricultural production and household use. By working through local NGOs to implement these projects CARE has been able to provide timely assistance to remote communities outside of its main target area.

At present CARE's main partnership drought response initiative is its Food Assistance to the Afghans (FATTA-II) project. FATTA's goal is to lessen the food vulnerability of drought-affected households and repair basic infrastructure through food-for-asset creation (FoodAC) activities. With support from OFDA and the World Food Programme (WFP), the project is working through local NGOs, AREA, ADA and CHA, to distribute food to 48,000 highly vulnerable families. The project recently resumed operations in five provinces of Afghanistan. 
In addition to these emergency programmes, CARE has continued operating the following projects:

\section{Water and Sanitation Project}

The Water and Sanitation Project aims to provide clean drinking water and improve the overall health status of some of Kabul's poorest neighborhoods. With support from OFDA, this project continued throughout the post-September $11^{\text {th }}$ period to ensure that families did not go without clean water. On average, the project's two water pumping stations provided 4,428 cubic meters of water each day for 38,000 families in eight districts of Kabul. In addition, the project provided 3,274 cubic meters of water for 2,490 families living in the bombed-out Russian Embassy compound. These families, originally from the Shamali Valley, were displaced from their homes by the Taliban in 1999 and only within the last two months have returned to their home villages.

For the last 18 months, CARE has been working with female health educators to teach hygiene classes to families living in the six districts, and they have already reached more than 40,000 households. Health education topics included: personal hygiene, safe methods of water storage, waste disposal, insect control, diarrhea prevention and treatment, and nutrition. CARE's health educators noted that the communities were very receptive to the in-home training sessions, and that positive improvements in health and hygiene are already apparent in these areas.

In January, with support from ECHO, CARE started a massive clean-up campaign to clear rubble and garbage from the streets and drainage ditches of six districts in

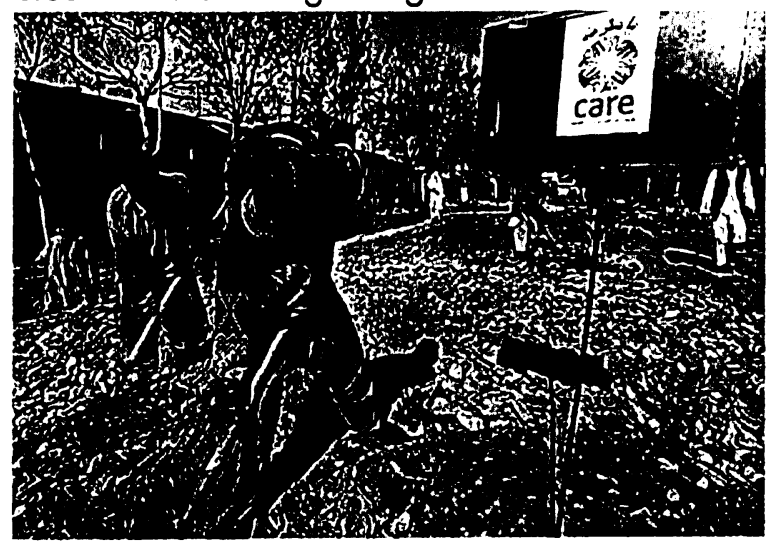

Kabul. There has been no garbage clearing in Kabul for more than 10 years, and the streets have been cluttered with rubbish and debris. Workers are resurfacing 112 miles of roads with gravel and lining them with drainage ditches. The workers receive approximately $\$ 1$ a day for their labour, equal to the cost of an eight-pound bag of flour. Through the project CARE is providing jobs for over 3,000 Afghans over the next six months.

\section{Assistance to Widows in Kabul}

There are an estimated 30,000-50,000 war widows in Kabul, with little or no means of support. The widows' situation became even more precarious in 1996 under Taliban rule as women could not travel without a male relative and were forbidden to work in most sectors. These conditions led CARE to expand its food distribution activities to 10,000 widows living in three districts of Kabul. Originally only a winter feeding programme, CARE's food distribution became year-round after the Taliban took Kabul. The programme supplies a monthly food ration of wheat, beans and cooking oil, equivalent to half of the monthly nutritional needs for a family of five. CARE distributes 4,000 tons of food annually to 10,000 widows $(60,000$ people 
total). Just prior to the start of the bombing in October, CARE distributed an emergency six-month ration to all of the widows because it was uncertain when monthly distributions could resume. The regular distributions started again in January 2002.

In addition to distributing food, CARE is providing health education to widows, with topics including personal hygiene, water and sanitation, nutrition, diarrhea treatment, iodine and vitamin A deficiency, malaria and immunization. Also CARE is helping dozens of women in Kabul to supplement their income by sewing uniforms for vulnerable girls returning to school. Working in three centers in Kabul, about 80 widows are helping to sew 8,000 school uniforms for families who cannot afford to buy them.

Sally Austin, assistant country director for CARE in Afghanistan, explained CARE's commitment to assisting Afghan women: "CARE was able to employ more than 70 women in its programmes, even during the Taliban. Now that conditions are more conducive to projects working with and for women, CARE is expanding previous pilot activities which train women in basic health and nutrition, and provide skills in sewing, embroidery, animal husbandry and vegetable gardening. These programmes are key in helping provide new sources of income for women."

In the gardening programme, widows improve
their family health and income by growing
tomato, onion, okra, eggplant, spinach,
carrot, pumpkin and other vegetables in their
home gardens. According to one participant
in the programme, "My family has benefited in
so many ways from our home garden. We
save money, because we no longer have to
buy vegetables in the market. The CARE
trainers taught me how to dry vegetables so I
can store them throughout the year. My
family's health has improved, and my children
no longer have iron and iodine deficiencies."

\section{Rural Assistance Programme}

CARE's Rural Assistance Programme (RAP) aims to support the livelihoods of rural families by promoting food production, improving health and sanitation, and enhancing the role of women in the community development process. The programme has three main components (rural infrastructure, income generation and agricultural development). In addition to implementing activities directly, RAP links communities to other, local service providers in order to foster longer term partnerships for assistance. Rural assistance activities have been the core of CARE's programming for over 12 years, during which time they have assisted over one million people through rehabilitation of agriculture and other rural infrastructure. To reach parts of the population who do not fully benefit from the rural engineering activities, RAP has designed a range of income generation and other initiatives aimed at supporting the landless, disabled, women and other vulnerable groups. 
With support from the EU, OFDA and WFP, RAP is currently operating in 5 provinces of central and southeast Afghanistan, with plans to expand to areas in the Shomali Valley north of Kabul. Although RAP was suspended in September because of security concerns, much progress has been made since the programme restarted in December 2001. Some of the accomplishments have included:

- Analyzed 81 communities and selected 53 to participate in RAP activities.

- Approved 337 "micro-projects", including road repair, water system construction, erosion control, and irrigation system repair. Twelve of these projects have been completed and most will be completed later this year.

- Trained 74 women in carpet-weaving, 40 women in tailoring, 140 women in livestock husbandry, and 20 young men from landless families, through CARE's work with local partners.

- Trained 2,300 women in health and hygiene education.

All RAP "micro-projects" are targeted towards high-need communities, such as those destroyed by war or seriously affected by drought. Most of the RAP communities experienced a high level of out-migration due to conflict and drought, so RAP is helping improve local infrastructure to enable displaced families to return to their home villages. Participation is a central principle in RAP's programming; the selected communities are mobilized to analyze and develop solutions to local problems and to contribute, to the extent possible, time, space and materials to support project activities. Within the current environment of prolonged drought, community participation has mainly taken the form of 'food for asset creation' (Food AC) projects.

In Khawajanaka village some 15 miles north of Kabul, RAP is helping residents repair their road that was destroyed by factional fighting in the early 1990s. Through a FoodAC programme, the community provides all the labour and local materials (such as rocks and sand) to repair the bumpy road. CARE provides the food contribution and assistance from project engineers.

Dr. Aman, a leader of the village council, recalled, "Before we fixed the road, no ambulances from Kabul could reach our village. If someone was sick, they had no way to get emergency medical care. Last year, four women died because they had no transportation to the hospital in Kabul. The new road is the greatest event in the history of our village!"

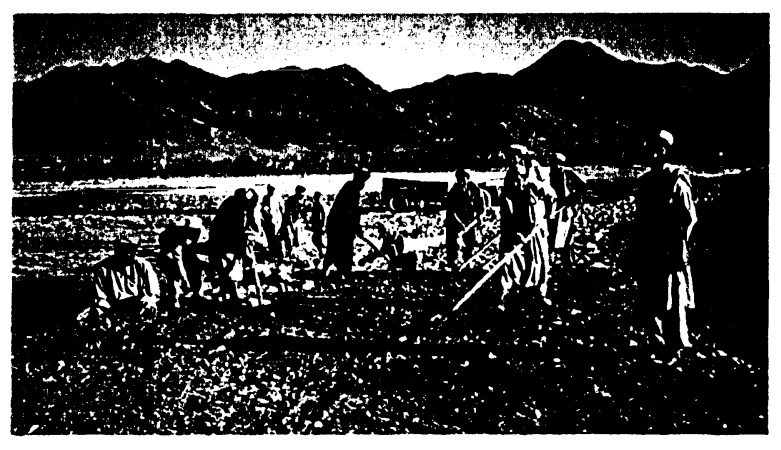

RAP makes specific efforts to ensure that women are included in the community development process and that they receive substantial benefit from the interventions. As the Rural Assistance Programme proceeds within the new political environment, gender and human rights issues will be given even greater attention. Furthermore, as longer-term projects become possible, RAP foresees expanding and improving its efforts in the areas of community capacity building and empowerment. 


\section{Basic and Girls' Education}

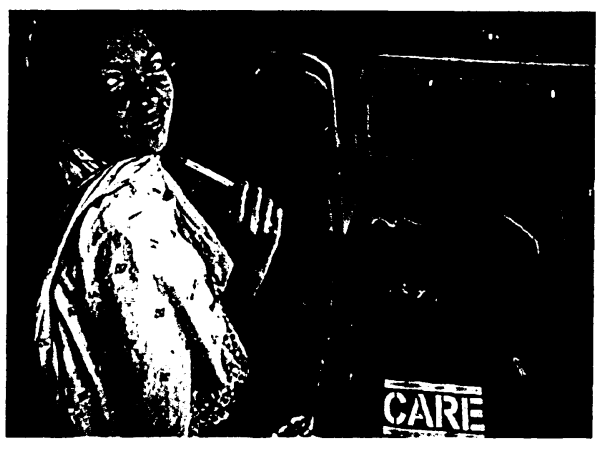

One of CARE's most innovative programmes in Afghanistan is the Community Organization for Primary Education (COPE) Project, which helps improve access to quality education for both boys and girls in seven districts of southeastern Afghanistan. The project, which promotes the establishment of community schools, provided culturally acceptable educational opportunities to girls even under the Taliban period. CARE provides teacher training and school materials, and the communities provide the school facilities (usually a home or community building), teacher salaries, and school management. Remarkably, over 95 percent of COPE schools remained operational after September 2001 and have actually taken in additional students from families fleeing from conflict.

COPE is currently reaching more than 23,000 students, 46 percent girls, through over 800 classes in 310 villages. A total of 44 new schools with 5,032 students opened in the last six months alone. In early January, COPE established its first two girls' schools in Chakadara District of the Shamali Valley. With additional funding, COPE plans to expand operations to southern Hazarajat.

Following the recent political changes in Kabul, CARE has been able to further expand its education programme activities. Representatives from CARE Afghanistan were invited to the Government's official "return to school" celebration in Kabul attended by Hamid Karzai. It is estimated that at least 4,000 female primary-school teachers have returned to the reopened classes in Kabul. However, the last time many of these teachers stepped into a classroom was before the Taliban came to power in 1996. To ensure that the teachers are equipped with adequate knowledge and skills to provide quality education, CARE started up a new female teacher training programme. The project is now working intensively with 35 senior teachertrainers, who in turn are responsible for providing basic training to 1,860 teachers in Kabul. The first training ended in late-March, and the teacher-trainer "graduation ceremony" was attended by representatives from the Ministry of Education.

In February, CARE started a new project designed to reach out-of-school girls in Kabul. The girls in Kabul, aged 9-14, have received little or no formal education since they were unable to attend school under the Taliban. Because the children are older than most primary school students, many are embarrassed to attend school with six and seven year-olds. The project "fast-tracks" the students so that they will be able to finish first

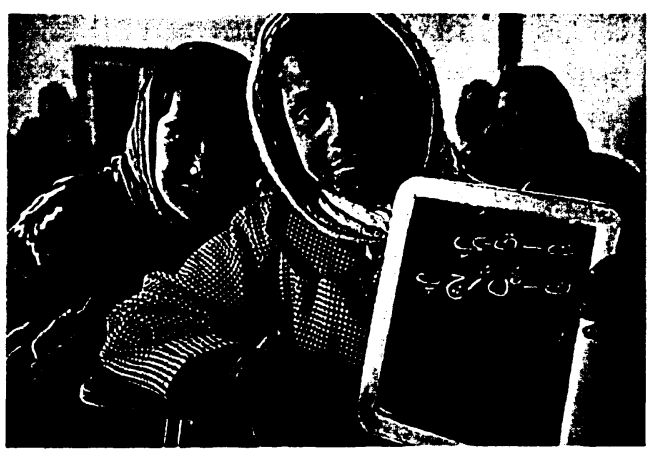
and second grades by the end of the school year in November. Then they will be able to rejoin a regular third grade class, or for the older students, to finish their sixth grade education by the end of the third year. Approximately 1,000 girls in three districts of Kabul will attend these accelerated learning centers. 


\section{Local Capacity Building}

CARE Afghanistan's Partnership Umbrella Initiative (PUI) was established in 1998 to provide training, technical support and grants to local non-governmental organizations (NGOs) for programmes aimed at overcoming poverty. Channeling funds to partner NGOs serves the duel purposes of financing meaningful projects while building the capacity of indigenous organizations to implement them. In addition to provision of funds, PUI makes efforts to strengthen the organizational capacity of its partners through training in leadership, management, monitoring, finance and other areas. Furthermore, CARE provides forums for local partners to meet with institutional donor reps to build the links between them so that in the future funding can be provided directly to grassroots organizations.

To date, PUI has established close relationships with over 60 local partners, who have carried out interventions in a wide range of sectors in Afghanistan and in refugee communities in Pakistan. In Kabul, for example, PUI is supporting a vocational training school for homeless street children (see photo). The youngsters attend class in the morning and learn valuable trades in the afternoon calligraphy, woodworking, painting, tailoring and electronics. The children also receive breakfast and lunch at the center. The items produced by the children are sold at the center and in local handicraft stores.

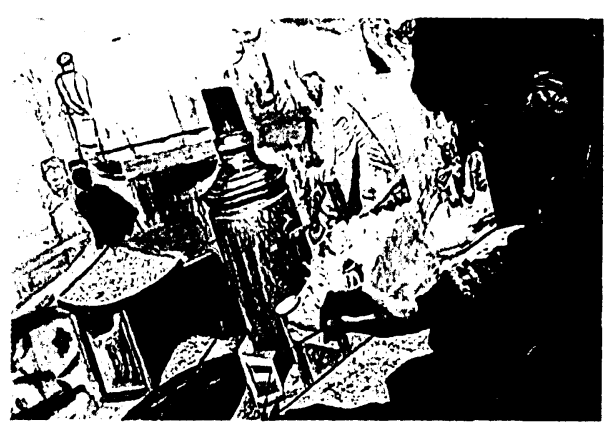

Although its activities were suspended in September, with funding from DfID, PUI restarted in January 2002 with a series of "quick impact projects" lasting between 1-3 months each. A total of 22 small projects were funded, including school reconstruction, fertilizer and tool distribution, orchard rehabilitation and loans for women's small businesses. Additionally, in response to life threatening conditions caused by drought, conflict and winter conditions in Ghazni province, PUI managed the distribution of non-food items to 18,000 IDPs and other vulnerable people.

While local partners are responsible for implementation, PUI's main roles in these initiatives are proposal review and selection, financial auditing of the partners, and monitoring of project activities. The monitoring visits have proved useful in overcoming challenges faced by the projects. For example in Jaghatu district, when ethnic divisions led to uneven distribution of winterization kits, the PUI monitor was able to successfully facilitate negotiations between two conflicting groups thereby ensuring an equitable distribution process.

In addition to the Partnership Umbrella Initiative, CARE has made partnership with local NGOs a central part of its Emergency Response and Rural Assistance programmes. With a well established network of local partners CARE has been able to reach a much larger number of beneficiaries with needed food and infrastructure development assistance across a wider area in a more cost-effective manner than through direct implementation. Increasing the number and quality of partnerships with local organizations remains a guiding principle in CARE Afghanistan's Long Range Strategic Plan. 


\section{Advocacy Initiative}

CARE is engaging in advocacy work to strengthen and augment its 'on the ground' efforts to ensure the sustained and equitable development of Afghanistan. CARE's advocacy efforts are aimed at influencing policies that will have a meaningful impact on a larger part of the population than it could ever reach through direct service provision. Through principled engagement with funding agencies and other key national and international decision-makers CARE believes it can bring its experience to bear on development policy affecting Afghanistan. In close collaboration with other agencies, CARE has identified and is active in advocating for the following issues:

- International Engagement: At present the international community is extensively engaged in the rebuilding of Afghanistan. However, based past experiences, Afghans have serious concerns that this interest could fade rapidly. A major priority of CARE is influencing key international donors to honour and sustain their funding commitments towards Afghanistan.

- Peace and Security: By assisting communities to meet their basic needs CARE is creating alternatives to violence as a means of livelihood. In addition, advocacy on security issues at the national and international levels is required to bring wider and sustainable peace and stability to the country. In particular, CARE is advocating for the expansion of the international peacekeeping force mandate outside of Kabul, and its extension beyond June 2002, until an Afghan security force that is appropriate to the country's security needs is trained and in place.

- Civil Society 'Space': 'Because of their long-standing experiences with and commitments to the development of Afghan communities, NGOs have important contributions to make towards the design of appropriate policy in Afghanistan. CARE is working to ensure the regulatory frameworks being put in place create an enabling environment for international and local NGOs not just to implement projects, but to participate as active members of civil society.

- Gender /ssues: While the retreat of the Taliban has had some positive effects on female access to education and employment, Afghan women are still denied many basic rights and thus remain amongst the most vulnerable groups. Central to CARE's advocacy strategy will be promoting the rights of Afghan women and ensuring their participation in the development of their country and communities.

To realize these advocacy objectives CARE will work to harness the efforts of a wide array of civil society, government, UN and other actors. By bringing together likeminded groups to speak out on critical issues affecting Afghanistan, CARE believes it can direct the heightened international on Afghanistan towards the creation of policies that promote lasting peace and development. Internally, CARE will strive to build the synergy among its advocacy, eternal relations and communications teams to promote needed policy change. To ensure the advocacy positions are reflected and reinforced in its programmes, CARE will carry out training on rights based approaches, gender and advocacy for key staff from CARE and partner organizations. Building the capacity and awareness at the field level is aimed at increasing the participation of primary stakeholders in setting the advocacy agenda, a critical aspect in ensuring it is firmly rooted in the Afghan context. 


\title{
Conclusion and Future Directions
}

CARE has responded to the humanitarian crisis in Afghanistan by immediately providing food, shelter, clothing and other emergency supplies, and also by expanding its existing poverty eradication programmes in widows' support, education, water and sanitation, rural assistance and local capacitybuilding. As Afghanistan continues through a difficult period of healing and reconstruction, CARE is committed to facilitating this process in partnership with Afghan communities, local government, and the international community.

The recent political changes in Afghanistan have brought a tangible optimism about the future, as well as new opportunities to assist Afghan communities. CARE is currently investigating how it can best support the rehabilitation and development process within this new context. Because of its extensive experience and skilled staff CARE is in a strong

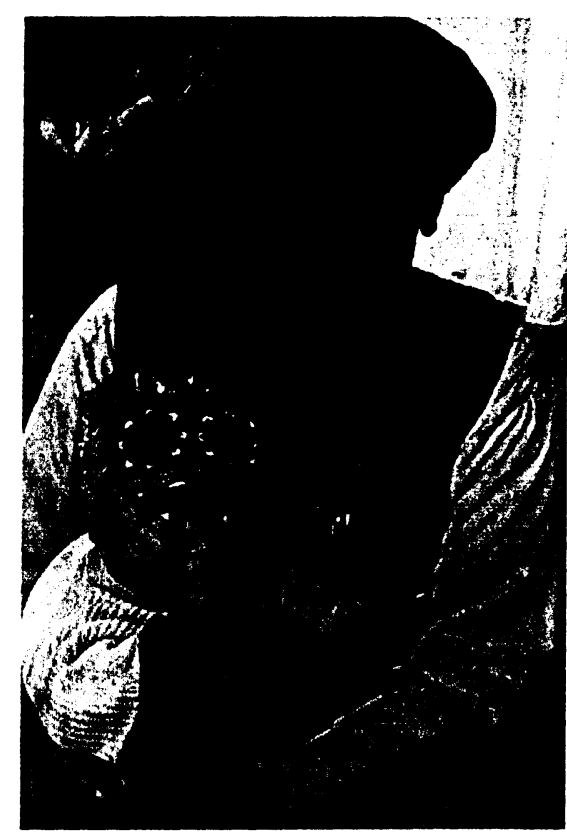
position to improve access to education, employment, clean water and other basic needs in vulnerable Afghan communities. In addition, CARE sees an opportunity to increase its role in capacity building at the community, provincial and national levels. CARE is in the process of.designing programmes to strengthen civil society and community organizations in the areas of human rights protection, peace building / conflict resolution, and in undertaking advocacy on these issues. CARE is also reorienting its programmes to work in closer partnership local government with the aim of building institutional capacity of the ministries responsible for social services and development issues.

In conclusion, CARE would like to thank its donors for their past and continuing support of its important relief and rehabilitation programs in Afghanistan, while at the same reaching out to encourage potential supporters. For more information on how you can contribute to CARE Afghanistan's programmes, please contact:

\author{
Paul Barker, Country Director \\ (barker@care.org) \\ or \\ Sally Austin, Assistant Country Director - Programme \\ (austin@care.org)
}



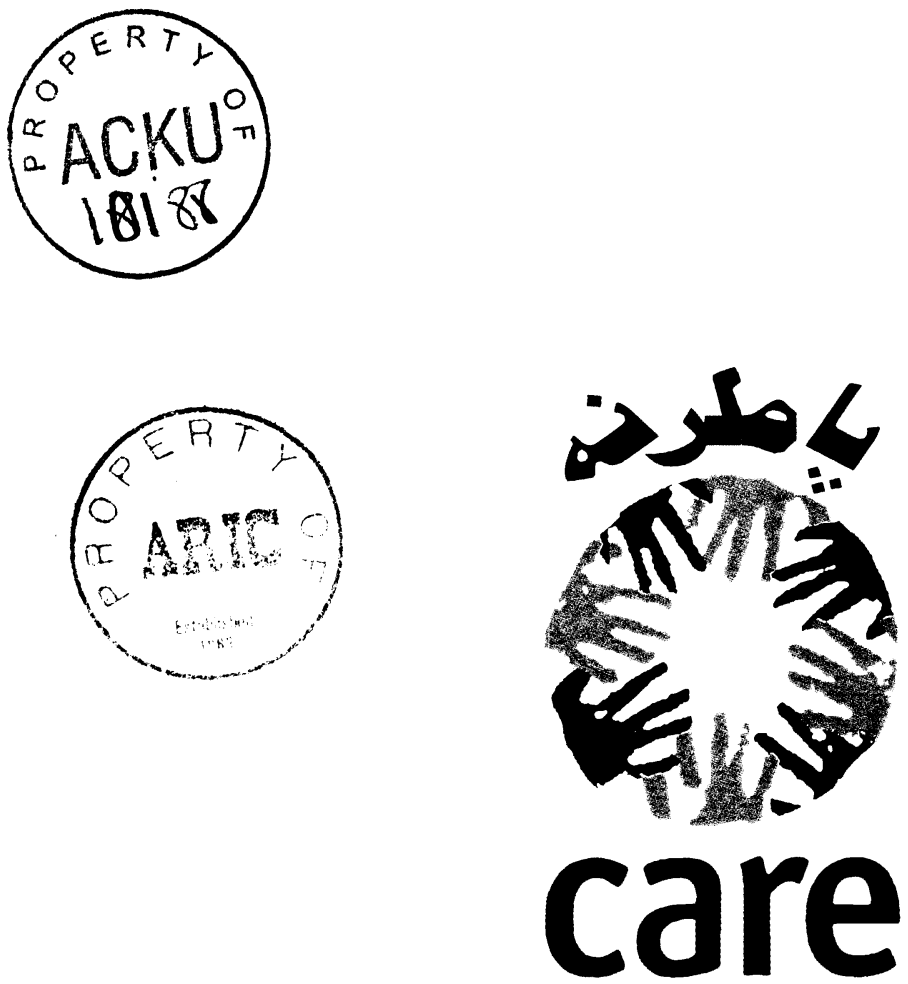

HEAD OFFICE

CARE International In Afghanistan

Haji Yaqoob Square, Park Road.

Shar-e-naw. Kabul - Afghanistan

Tel: 32621/30808/2201098/2201101

International Line: 0093-2-290064

Sat Phone: 00873762212633

00-873-762-212-630 or $00-873-763-221-868$

Fax: 00873762212631

Email: carekbl@atge.automait.com

\section{PESHAWAR OFFICE:}

6-Park Lane, Park Road

University Town. Peshawar - Pakistan

Tel: $5700328 / 5700017 / 852321$

$852318 / 850614$

Fax: 0092-91-841826

Email:afghan@care.org

website: www.care.org

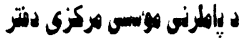

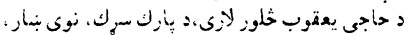

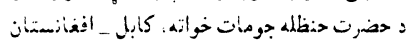

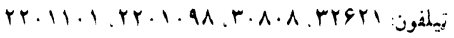

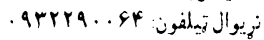

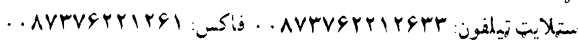

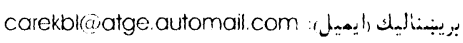

